\title{
ANALYSIS OF MARITIME PIRACY AND ARMED ROBBERY ATTACKS AGAINST SHIPS
}

\section{Nur Jale ECE ${ }^{1}$}

\begin{abstract}
Maritime pirates usually attack in commercially narrow, risky and strategic waterways. In this paper, maritime piracy and armed robbery attacks against ships in Gulf of Aden, Somalia, Indonesia and other risky high seas are analyzed for the period 2009-2013. Primary factors behind the acts of maritime piracy attacks, international efforts to combat maritime piracy which includes legal issues, related agreements, regulations, clauses and multinational efforts have been reviewed in this paper. The Chi Square Test $\left(\chi^{2}\right)$ was used to determine whether a relationship exists between non-parametric variables such as attacks by years, months and hours; type of attacks; type of vessels attacked; attacks by regions and locations; latitude and longitude of attacks and the number of pirates who attacked against ships. A general evaluation was conducted and further required measurements and suggestions are proposed to combat maritime piracy and armed robbery against ships.
\end{abstract}

Keywords: Maritime security, maritime piracy, Somalia.

1 Dr. T.C. Başbakanlık, Özelleştirme İdaresi Başkanlığı, jaleece2004@yahoo.com 


\title{
GEMILERE KARŞI SILAHLI SOYGUN VE DENİZ HAYDUTLUĞU SALDIRILARININ ANALIZI
}

\begin{abstract}
ÖZET
Deniz haydutlarl genellikle dar, riskli ve stratejik önemi haiz dünya ticaretinin geçtiği su yollarında saldırı yapmaktadır. Bu çalışmada, 2009-2013 dönemini içeren Aden Körfezi, Somali, Endonezya ve diğer yüksek riskli bölgelerde gemilere yönelik deniz haydutluğu ve silahlı soygun saldırllarl analiz edilmiştir. Çalışmada deniz haydutluğunun başlıca nedenleri, deniz haydutluğu ile mücadelede yasal konular, ilgili anlaşmalar ve düzenlemeler, uluslararası çabalar incelenmiştir. Saldırı yılları, ayları ve saatleri, saldırı türü, saldırıya uğrayan gemi türleri, saldırı bölgeleri ve lokasyonları, saldırı bölgelerinin enlem ve boylamları ve haydut saylsı gibi parametrik olmayan değişkenler arasındaki ilişki olup olmadığını belirlemek için Ki-Kare Testi $\left(\chi^{2}\right)$ kullanılmıştır. Genel bir değerlendirme yapılmış ve deniz haydutluğu ve silahlı soygunla mücadelede gerekli önlemler ve alınması gerekli tedbirler önerilmiştir.
\end{abstract}

Anahtar Kelimeler: Deniz güvenliği, deniz haydutluğu, Somali.

\section{INTRODUCTION}

Nearly $90 \%$ of goods imported and exported globally are transported by sea expecially by narrow, high risk and strategically important choke points such as the Malacca or Singapore Straits, the Suez Canal, Bab el-Mandeb Strait, Gulf of Aden (Çaycı, 2009: 9-12). Maritime pirates usually attack in commercially strategic narrow and/or risky waterways. The threat of piracy is a major international dimension of maritime security issue in the world. The hijacking of crew or vessels on the narrow shipping lanes or sea routes causes seriously delays in or damage to international maritime trade (Ece, 2013: 30-32). The blockage of a choke points, even temporarily, can lead to substantial increases in total energy costs as well as shipping accidents which can lead to disastrous oil spills (eia.gov, 2015: 1). Economically hard hit by piracy are ship owners, exporters of shipped cargo, carriers and insurance firms. Shipping companies may have to foot hefty ransom demands. Rising insurance premiums may exact its toll on businesses. Piracy could also impact on the safety of navigation (Chew, 2005: 74).

A total of 264 incidents of piracy were reported to the International Maritime Bureau's (IMB) Piracy Reporting Centre (PRC) in 2013. This is an $11 \%$ decrease from the 2012 figures of 297 and massive $41 \%$ decrease from 2011 (439 attacks). Most of these attacks occurred in South East Asia and respectively in Africa, Indian Sub-Continent, 
America and Far East in 2013. Attacks have dropped significantly in Gulf of Aden, Somalia and Red Sea in 2013 due to the increased and aggresive patrols by the littoral states authorities since July 2005. The attacks are continuing to increase in the waters of the Indonesia, Nigeria, Bangladesh, Vietnam, Benin and India in 2013. Other risky regions are Togo, Egypt Gulf of Guinea, Tanzania, Peru, Malaysia, Malacca/ Singapure Straits, South China Sea and Colombia (IMB ICC Report, 2013: 21-22).

The attacks are not only costly in terms of business losses; they can also be deadly. Pirates are particularly violent, with guns reported in 915 of the attacks in 2009-2013 and 71 of the attacks in 2013. Pirates have attacked all types of vessels; general cargo, bulk carrier, all types of tanker, Ro-Ro, container, cruise ships, ferries, fishing vessels, tugs, sailing yatch and other smaller boats (ICC, IMB Report, 2013:11,14). Somali pirates also target the UN aid ships carrying food and other supplies to Somali refugees. According to the International Maritime Organization (IMO), piracy poses a tremendous terrorist threat and maritime piracy is the potential threat of seaborne terrorism. However, Menefee (1998) points out piracy and terrorism have been considered separate and distinct, with the former including 'private' and the latter 'non-private' ends. Consequently, The pirates and terrorists use similar tactics, maneuver in sensitive and conflict-prone geography, and that the cross-influence between them is increasing (Reinhardt, 2012: 1-3).

It estimates that maritime piracy cost the global economy between $\$ 5.7$ and 6.1 billion in 2012 (One Earth Future Foundation, 2012:1). The piracy attacks have forced ships to opt for the more costly and lengthy alternative route named the Cape of Good Hope instead of the Suez Canal.

The objective of this study is to analyze maritime piracy and armed robbery attacks occurred all over the world during the period 2009-2013 by using The Chi Square Test $\left(\chi^{2}\right)$ to interpret the relationships between the non-parametric parameters such as attacks as years, months and hours, type of attacks, type of vessels attacked, attacks as regions and locations, latitude and longitude of attacks and the number of pirates who attacked against ships and to purpose further required measurements and suggestions to combat maritime piracy and armed robbery attacks against ships. 
The paper is organized in five sections. Section 2 discusses primary factors behind the acts of maritime piracy attacks. Section 3 includes international efforts to combat maritime piracy and armed robbery attacks, Section 4 entitled "Material and Methodology" performs data collection and statistical data analysis. The Chi Square Test $\left(\chi^{2}\right)$ was also used to interpret the relationships between the non-parametric variables in the period 2009-2013. Section 5 offers a number of conclusions and provides required measurements and suggestions for the maritime sector, the governments and multinational antipiracy patrols to be taken precuations and academic researchers to combat maritime piracy and robbery attacks.

\section{PRIMARY FACTORS BEHIND THE ACTS OF MARITIME PIRACY ATTACKS}

Piracy has traditionally been "fed" by two underlying drivers, which when taken together, have provided an almost limitless range of vulnerable targets from which to choose: the enormous volume of commercial freight that moves by sea and the necessity of ships to pass through congested and high-risk choke points maritime choke points such as the straits Malacca, Hormuz, Panama Canal, Bab el-Mandeb and Suez Canal, the Straits of Strait of, the Malacca Straits and the Bosphorous Straits (Chalk, 2009: 2).

Geography is an essential condition required for the emergence of piracy. The Gulf of Aden is the main trade route between Europe, the Middle East, and Asia, with approximately 16,000 ships navigating this area each year. The maritime industry off the Somali coast has grown over the years, and today, the Gulf of Aden serves as host to $12 \%$ of global maritime trade and $30 \%$ of the world's crude oil shipments (Charlebois, 2012: 12).

Given the lack of economic prospects resulting from the dire state of affairs in Somalia - including continued conflict, the lack of any functional government, poverty, reductions in wages, hikes in food prices, and high unemployment rates, inadequate training consequently bringing with it a related rise in criminal activities, including piracy (Charlebois, 2012: 13). Somali pirates target the United Nations (UN) aid ships carrying food and other supplies to Somali refugees (WFP, 2009). 
Regional internal political and economic instability and loopholes in legal instruments, as well as corruption and and easily compromised judicial structures (Chalk, 2008: 10). With no sovereign government in place, gangs have virtual free-run of the area (Chalk, 2009: 3). The civil war that broke out in the 1990s in Somalia and the ensuing incapacity of the central government to clamp down on crime encouraged new pirates.

Insufficient coastline and port surveillance and inspection capacity. Poorly trained or equipped coastguard, adequate staff, or local law enforcement in hot spots at high-risk for piracy. Many governments have already limited resources for monitoring territorial waters. Lax coastal and port-side security have played an important role in enabling low-level pirate activity, especially harbor thefts against ships at anchor (Chalk, 2009: 3).

The efforts of the Somalian people to protect their fish due to illegal fishing. Somali waters have a high potential for fishing. A large number of foreign vessels illegally fishing in Somali waters and serious pollution caused by vessels discharging toxic waste. Many of the pirates operating in Somalia are former fishermen who attack foreign fishing boats claiming that they are illegally fishing Somali waters and threatening their business (UNEP,2005: 133; KAIPTC, 2011: 11).

Starting from the early 1980s and continuing into the civil war, discharge of toxic and chemical waste and dumping of the hazardous waste along Somalia's coast comprised uranium radioactive waste, lead, cadmium, mercury, industrial, hospital, chemical, leather treatment and other toxic waste by foreign ships caused serious damage to marine ecosystem of these waters also producing a negative effect on local fishing (UNEP,2005: 134).

The prospect of windfall profits. The worsening state of affairs in regional countries such as Somalia has made illegal activities an increasingly attractive and viable business. The ready willingness of shipowners to pay increasingly large sums of money for the return of their vessels and cargoes has provided added incentive to engage in maritime crime (Chalk, 2009: 3).

Maritime piracy has also been linked with ideological aims, thus suggesting that piracy can evolve into more deadly forms of maritime terrorism. Despite reports that illustrate the operational collaboration between the militants and pirates. It has been reported that various 
elements in the Somali piracy community have been linked with members of insurgency groups (Oilprice, 2010; Ece, 2012: 33-49).

\section{INTERNATIONAL LEGAL FRAMEWORK, ARRANGEMENTS AND EFFORTS TO COMBAT MARITIME PIRACY}

International efforts to combat maritime piracy must be examined from three perspectives: the international legal framework for controlling maritime piracy; arrangements adopted by International Maritime Organization (IMO) and The European Union (EU); and multinational efforts.

\subsection{International Legal Framework To Control Maritime Piracy}

International legal framework largely consists of treaties and conventions which either set out rules or impose obligations upon contracting countries to control maritime piracy unilaterally or collectively. The major international treaties and conventions concerning piracy control are the 1958 Geneva Convention on the High Seas; the 1982 United Nations Convention on the Law of the Sea (UNCLOS); 1988 The United Nations Convention Against Illicit Traffic in Narcotic Drugs and Psychotropic Substances (Article 17) (Ece, 2012: 33-49).

\subsubsection{The United Nations Convention on the Law of the Sea (UNCLOS)}

The UNCLOS Convention contains a number of provisions on piracy control. Articles 100 to 107 and 110 set out the principles on piracy control and impose obligations upon contracting countries to engage in collective efforts to combat piracy committed on the high seas and outside the jurisdiction of a country. Article 100 of the UNCLOS requires all States to cooperate to the fullest possible extent in the repression of piracy on the high seas or in any other place outside the jurisdiction of any State.

Articles 100 to 107 of UNCLOS govern the provisions relating to the definition, jurisdiction, and obligations of member states seeking to pursue, capture, and prosecute maritime pirates. Under UNCLOS, there are four essential elements to the definition of piracy: 1) an illegal act involving violence, detention, or depredation 2) committed for private 
ends 3) on the high seas 4) involving at least two ships. UNCLOS also reaffirms the idea of universal jurisdiction because it gives every state jurisdiction to seize and prosecute pirates according to that state's domestic laws (Chang, 2010: 275).

\subsubsection{Convention for the Suppression of Unlawful Acts Against the Safety of Maritime Navigation, 1988 (SUA)}

The Convention for the Suppression of Unlawful Acts against the Safety of Maritime Navigation 1988 (SUA). The main purpose of the SUA convention is to ensure that appropriate action is taken against persons committing unlawful acts against ships consistent with applicable international law. These actions include: a) seizes or exercises control over a ship by force or threat thereof or any other form of intimidation, $b$ ) performs an act of violence against persons on board ships if that act is likely to endanger the safe navigation of that ship, c) to create criminal offences; establish jurisdiction; d) accept delivery of persons (Çayc1, 2009:9-12). The convention obliges Contracting Governments either to extradite or prosecute alleged offenders.

\subsection{United Nations (UN) Security Council Resolutions}

Piracy has been an increasingly important issue for the United Nations (UN) throughout 2008, as is evident with Security Council resolutions. The United Nations (UN) Security Council Resolutions 1801 (2008), 1816 (2008), 1838 (2008), 1844 (2008), 1846 (2008), 1851 (2008) and of UN General Assembly Resolution 63/111 which all make explicit reference to the growing concern over piracy and provide recommendations for action (Çaycı, 2009: 9-12). The Security Council authorized all states capable of lending assistance to undertake all necessary measures "appropriate in Somalia" to interdict the pirates at sea and on land.

\subsection{International Maritime Organization (IMO) Resolutions and Circulars}

International Maritime Organization (IMO) Resolutions and Circulars include recommendations and measurements to governments, shipowners, ship operators, shipmasters and crews for combating piracy and armed robbery against ships to enhance maritime security. Some of the IMO Resolutions are; Resolution A.545 (XIII) Measures to prevent and suppress piracy and armed robbery against ships (1983); Resolution 
A. 683 (17) "Prevention and suppression of acts of piracy and armed robbery against ships" (1991); Resolution A.738 (18) "Measures to prevent and suppress piracy and armed robbery against ships" (1993); Resolution A.923(22), "Measures To Prevent The Registration Of Phantom Ships" (2001); Resolution A. 1025 (26) "Code Of Practice For TheI Investigation Of Crimes Of Piracy And Armed Robbery Against Ships" (2009); Resolution A.1044(27), "Piracy And Armed Robbery Against Ships In Waters Off The Coast Of Somalia" (2011); Resolution A 27/Res.1044 "Piracy and Armed robbery against ships in waters off the coast of Somalia" (2011) and Resolution Msc.324(89) "Implementation Of Best Management Practice Guidance" (2011) (IMO, 2015a: 1; ClassNK, 2015: 1).

Recognizing the importance of domestic laws in the successful prosecution of pirates, the IMO passed Resolution A. 1025 (26) which encourages states to ratify enabling legislation that would codify theiruniversal jurisdiction over piracy and establish procedures to facilitate the prosecution of pirates. Resolution A. 1025 (26) also recommends guidelines for piracy investigation strategies. The resolution suggests that flag states of the victimized ship should take the lead in investigations for piracy incidents; conversely, the state in whose territorial waters the incident occurs should bear the responsibility to investigate armed robbery at sea (Chang, 2010: 277).

Some of the IMO Circulars are given as follows (IMO, 2015a: 1; ClassNK, 2015: 1);

IMO Circulars concerning piracy and armed robbery against ships in waters off the coast of Somalia: MSC.1/Circ.1233, "Piracy and armed robbery against ships in waters off the coast of Somalia" (2007); MSC.1/Circ.1302, Piracy And Armed Robbery Against Ships In Waters Off The Coast Of Somalia (2009); MSC.1/Circ.1332 "Piracy And Armed Robbery Against Ships In Waters Off The Coast Of Somalia includes: Best Management Practices to Deter Piracy in the Gulf of Adenand off the Coast of Somalia; and Additional guidance to vessels engaged in fishing" (2009).

IMO Circulars concerning recommendations and guidance to governments, shipowners and ship operators, shipmasters and crews: MSC.1/Circ.1333 (26 June 2009) "Piracy And Armed Robbery Against Ships: Recommendations to Governments for preventing and suppressing piracy and armed robbery against ships" (2009; MSC.1/Circ.1334, "Piracy And Armed Robbery Against Ships, "Guidance to shipowners 
and ship operators, shipmasters and crews on preventing and suppressing acts of piracy and armed robbery against ships" (2009). MSC.1/Circ.1335, "Best Management Practices to Deter Piracy in the Gulf of Aden and off the Coast of Somalia developed by the industry" (2009).

IMO Circulars concerning Privately Contracted Armed Security Personnel: MSC.1/Circ.1405/Rev.2, "Revised Interim Guidance To Shipowners, Ship Operators And Shipmasters On The Use Of Privately Contracted Armed Security Personnel On Board Ships In The High Risk Area" (2012); MSC.1/Circ.1406/Rev2, "Revised Interim Recommendations for Flag States regarding the use of Privately Contracted Armed Security Personnel on board ships in the High Risk Area" (2012); MSC.1/Circ.1408/Rev.1,"Revised Interim Recommendations for Flag States regarding the use of Privately Contracted Armed Security Personnel on board ships in the High Risk Area" (2012); MSC.1/Circ.1443, "Interim guidance to private maritime security companies providing privately contracted armed security personnel on board ships in the High Risk Area" (2012). MSC.1/Circ.1444, "Interim guidance for flag States on measures to prevent and mitigate Somalia-based piracy" (2012).

\subsection{European Legislation on Maritime Security}

The European Union (EU) legislation consists in the combination of preventive measures contained in the Regulation on enhancing ship and port facility security. EU) legislation on maritime security are given as follows (EU, 2015: 1,2).

Ship and port facility security: Regulation (EC) No 725/2004 on enhancing ship and port facility security- The main objective of this Regulation is to implement Community measures aimed at enhancing the security of ships through measures of preventive nature used in international trade and associated port facilities in the face of threats of intentional unlawful acts (including piracy and armed robbery at sea).

Port Security Directive: Directive 2005/65/EC on enhancing port security-The Directive complements the security measures introduced by Regulation (EC) No 725/2004 by making an entire port subject to a security regime in order to obtain maximum protection for maritime and port activities. 
Commission inspections in the field of maritime security: Commission Regulation (EC) No 324/2008 on procedures for conducting Commission inspections in the field of maritime security. In order to monitor the application by Member States of EU legislation on maritime security, the Commission conducts inspections to verify the effectiveness of national quality control systems and maritime security measures, procedures and structures at each level of each Member State and of individual port facilities and relevant companies.

Maritime Security Committee (MARSEC): MARSEC is a Regulatory Committee established by virtue of Article 11 of Regulation (EC) No 725/2004 and it also assists the Commission with regard to its activities under Directive 2005/65/EC. The Regulatory Committee is chaired by the Commission and consists of experts representing all Member States.

Commission Recommendation on measures for self-protection and the prevention of piracy and armed robbery against ships (2010/159/EU).

\subsection{Other Related Agreements and Regulations}

The Regional Cooperation Agreement on Combating Piracy and Armed Robbery against ships in Asia (RECAAP) was concluded in November 2004 by 16 countries and set up the RECAAP Information Sharing Centre (ISC) for facilitating the sharing of piracy-related information.

The Djibouti Meeting adopted the Code of Conduct concerning the Repression of Piracy and Armed Robbery against Ships in the Western Indian Ocean and the Gulf of Aden, which was signed and effective as from on 29 January 2009 by the representatives of Djibouti, Ethiopia, Kenya, Madagascar, Maldives, Seychelles, Somalia, the United Republic of Tanzania and Yemen. The signatories of the Djibouti Code of Conduct have agreed to implement and/or reinforce the following mechanisms and activities such as establishment of Piracy Information Exchange Centres and Regional Training Centre to be established in Djibouti (IMO, 2013a:1).

The International Ship and Port Facility Security (ISPS) Code came into force on 1 July 2004 to develop security measures applicable to ships and port facilities developed by the IMO. ISPS Code is a comprehensive set of measures to enhance the security of ships and port 
facilities, developed in response to the perceived threats to ships and port facilities. ISPS has been included as amendments to the International Convention for the Safety of Life at Sea (SOLAS), (1974/1988) on minimum security arrangements for ships, ports and government agencies. The Code has two parts, one mandatory and one recommendatory (IMO, 2015b: 1).

Automatic Identification Systems (AISs) are designed to be capable of providing information about the ship to other ships and to coastal authorities automatically. Regulation 19 of SOLAS Chapter V Carriage requirements for shipborne navigational systems and equipment sets out navigational equipment to be carried on board ships, according to ship type. The regulation requires AIS to be fitted aboard all ships of 300 gross tonnage and upwards engaged on international voyages, cargo ships of 500 gross tonnage and upwards not engaged on international voyages and all passenger ships irrespective of size. The requirement became effective for all ships by 31 December 2004 (IMO, 2013b:1).

The Long-Range Identification and Tracking (LRIT) system which is included in Chapter V of the SOLAS provides for the global identification and tracking of ships. LRIT was introduced as a mandatory requirement for the following ships on international voyages: passenger ships, including high-speed craft; cargo ships, including high-speed craft, of 300 gross tonnage and upwards; and mobile offshore drilling units. SOLAS contracting governments will be entitled to receive information about ships navigating within a distance not exceeding 1000 nautical miles (IMO, 2013c:1).

\subsection{Multinational Efforts To Combat Maritime Piracy}

Regional organizations such as NATO are permitted to take measures to secure their regions. The principal response mechanism has been the multinational antipiracy patrols such as Combined Task Force (CTF-150), Combined Task Force 151 (CTF 151), Combined Task Force 152 (CTF 152), NATO's Standing Naval Force Mediterranean (STANAVFORMED). The EU Operation Atalanta, enforced by the European Union's military capability, is called EU NAVFOR in the area. Under Operation Active Endeavour, which is a part of NATO's multifaceted response to the terrorist threat, NATO ships are patrolling the Mediterranean and monitoring shipping to help detect, deter and protect against terrorist activity (Ece, 2010: 16-17). 
Fleets, coastguards, police marine units, customs and other government agencies engaged in Southeast Asia are taking measures against the piracy threat; the efforts of the international community and coalition forces have in large part been successful (Ece, 2012). Southeast Asian countries, Nigeria and Somalia have agreed in principle to collaborate in the face of rising piracy attacks, including intelligencesharing and sea and air patrolling. Indonesia, Malaysia, and Singapore, all coastal states, have conducted joint naval patrols (Alessi and Hanson, 2012: 1-5).

Since 1 February 2009, Maritime Security Center Horn of Africa (MSCHOA) has established the Internationally Recommended Transit Corridor (IRTC) within the Gulf of Aden to improve the safety of shipping in these dangerous waterways; ships and boats are advised to travel in convoys. Military assets (Naval and Air) are strategically deployed within the area to provide protection and support to merchant ships.

Baniela (2010) analyzes piracy at sea in Somalia, to provide a general up-to-date vision of the problem which threatens the security of ships sailing in the Gulf of Aden. It is infered the consequence that since the 1980s, more sophisticated forms of piracy have been developed. Piracy is a land-based crime which is evident at sea; so the decisive factor is what happens on land. Baniela and Rios (2012) analyze the impact of the current strategy in the struggle against piracy in Somalia carried out by the international community. The study clarifies the international community requires a comprehensive and multi-faceted response of effective counter-measures, both onshore and offshore and the international community must implement land-based counter-measures.

\section{MATERIAL AND METHODOLOGY}

The piracy and armed robbery attacks data was acquired from the Piracy and Armed Robbery Incidents statistics of the ICC International Maritime Bureau's "Piracy and Armed Robbery Against Ships" Annual Reports for in the period 2009-2013. The piracy and armed robbery attacks data base contains 1851 actual and attempted attacks records which includes 16659 nonparametric data. The non parametric variables such as attacks by years, months and hours; type of attacks; type of vessels attacked; attacks by regions and locations; latitude and longitude of attacks and the number of pirates who attacked against ships were used in the analysis. The classification scale was used to define the non parametric variables and to divide sub groups. 


\subsection{Chi-Square Test}

In the study, Chi-Square Test $\left(\chi^{2}\right)$ which is a quantative measure was used to analyze whether a relationship exists between the non parametric variables for the period in 2009-2013. The significance level $(\alpha)$ was set at $5 \%$.

It was tested a hypothesis $H_{0}$ that fully specifies $p^{1}, \ldots \ldots, p k$, $H_{0}: p_{1}=p_{1}{ }^{(0)}, ; p_{2}=p_{2}{ }^{(0)}, \ldots \ldots \ldots \ldots, p_{k}=p_{k}{ }^{(0)}$,

$$
\begin{gathered}
\text { The formula for the } \chi^{2} \text { test statistic is: } \\
\chi_{\mathrm{k}}^{\mathrm{k}}=\sum_{\mathrm{i}=1}^{\left(\frac{\left.\mathrm{n}_{\mathrm{i}}-\mathrm{np}_{i}^{(0)}\right)^{2}}{\mathrm{np}_{\mathrm{i}}^{(0)}}\right.}=\sum_{\mathrm{i}=1} \frac{(\text { Observed Count in Cell } i \text { - Expected Count in Cell } i)^{2}}{\text { Expected Count in Cell } i}
\end{gathered}
$$

We can safely use the Chi-Square Test when (a) the samples are simple random samples; (b) all individual expected counts are 1 or more than 1 all $\left.\mathrm{E}_{\mathrm{i}} \geq 1\right)$; (c) no more than $20 \%$ of expected counts are less than 5; (d) the minimum expected count is at least equal to 1 . The P-value which is the probability of observing a sample statistic should also less than the significance level at 0.05 (Cochran, 1954: 417-451; Sheskin, D.J, 2004: 494-495).

\subsubsection{The Chi-Square Test Between Attacks by Years and Attacks by Regions}

There were 1851 piracy and armed robbery attacks during the 2009-2013 period. Most of these attacks occurred in 2010 with the frequency $445(24,0 \%)$. The least number of attacks occurred in 2013 with the frequency $264(14,3 \%)$ as shown in Table 1. Most of these attacks occurred in Africa with the frequency 1044 attacks $(56,4 \%)$ and respectively South East Asia with 428 attacks (23,1\%), America with 137 attacks $(7,4 \%)$, Indian Sub-Continent with 118 attacks $(6,4 \%)$ and Far East with 110 attacks (5,9\%) recorded in the period of 2009-2013 (IMB ICC, 2009-2013).

According to the IMB PRC the attacks in South Asia and Africa have dropped significantly due to the efforts of the international community and coalition forces, increased/active military action, military land based anti-piracy operations, preventive measures such as Best 
Management Practices (BMP) recommendations, implementation of International Recommended Transit Corridor (IRTC) that is protected by warships and increased privately contracted armed guards on board ships.

Table 1. Crosstabulation for Attacks by Years and Attacks by Regions

\begin{tabular}{|c|c|c|c|c|c|c|c|c|}
\hline \multirow[b]{2}{*}{ Years } & \multirow[b]{2}{*}{$\begin{array}{c}\text { Count } \\
\% \text { within } \\
\text { attacks by } \\
\text { years }\end{array}$} & \multicolumn{4}{|c|}{ Attacks y Regions } & \multirow[b]{2}{*}{$\begin{array}{l}\text { Far } \\
\text { East }\end{array}$} & \multirow[b]{2}{*}{ Oth. } & \multirow[b]{2}{*}{ Tot. } \\
\hline & & Africa & $\begin{array}{l}\text { South } \\
\text { East } \\
\text { Asia }\end{array}$ & $\begin{array}{c}\text { Indian } \\
\text { Sub } \\
\text { Cont. }\end{array}$ & $\begin{array}{c}\text { Ameri } \\
\text {-cas }\end{array}$ & & & \\
\hline \multirow[t]{3}{*}{2009} & Count & 264 & 45 & 29 & 37 & 23 & 8 & 406 \\
\hline & Expec. C. & 229,0 & 93,9 & 25,9 & 30,0 & 24,1 & 3,1 & 406,0 \\
\hline & $\%$ & 65,0 & 11,1 & 7,1 & 9,1 & 5,7 & 2,0 & 100,0 \\
\hline \multirow[t]{3}{*}{2010} & Count & 259 & 70 & 28 & 40 & 44 & 4 & 445 \\
\hline & Expec. C. & 251,0 & 102,9 & 28,4 & 32,9 & 26,4 & 3,4 & 445,0 \\
\hline & $\%$ & 58,2 & 15,7 & 6,3 & 9,0 & 9,9 & 0,9 & 100,0 \\
\hline \multirow[t]{3}{*}{2011} & Count & 293 & 80 & 16 & 25 & 23 & 2 & 439 \\
\hline & Expec. C. & 247,6 & 101,5 & 28,0 & 32,5 & 26,1 & 3,3 & 439,0 \\
\hline & $\%$ & 66,7 & 18,2 & 3,6 & 5,7 & 5,2 & 0,5 & 100,0 \\
\hline \multirow[t]{3}{*}{2012} & Count & 149 & 105 & 19 & 17 & 7 & 0 & 297 \\
\hline & Expec. C. & 167,5 & 68,7 & 18,9 & 22,0 & 17,6 & 2,2 & 297,0 \\
\hline & $\%$ & 50,2 & 35,4 & 6,4 & 5,7 & 2,4 & 0,0 & 100,0 \\
\hline \multirow[t]{3}{*}{2013} & Count & 79 & 128 & 26 & 18 & 13 & 0 & 264 \\
\hline & Expec. C. & 148,9 & 61,0 & 16,8 & 19,5 & 15,7 & 2,0 & 264,0 \\
\hline & $\%$ & 29,9 & 48,5 & 9,8 & 6,8 & 4,9 & 0,0 & 100,0 \\
\hline \multirow[t]{3}{*}{ Total } & Count & 1044 & 428 & 118 & 137 & 110 & 14 & 1851 \\
\hline & Expec. C. & 1044,0 & 428,0 & 118,0 & 137,0 & 110,0 & 14,0 & 1851 \\
\hline & $\%$ & 56,4 & 23,1 & 6,4 & 7,4 & 5,9 & 0,8 & 100,0 \\
\hline
\end{tabular}

Source: ICC International Maritime Bureau (IMB) Piracy and Armed Robbery Against Ships Annual Reports 2009-2013.

Hypothesis;

$\mathrm{H}_{0}$ : The attacks by years and attacks by regions are independent.

$\mathrm{H}_{1}$ : The attacks by years and attacks by regions are not independent.

The Pearson Chi Square value is 230,340 as shown in Table 2. The samples are simple random samples; all individual expected counts are more than 1 and $16,7 \%$ of expected counts are less than 5. Minimum expected count is more than $1(2,00)$. The sample size requirement for the chi-square test of independence is satisfied. Therefore, the Chi Square is used. 
Table 2. Chi-Square Test for Attacks by Years And Attacks by Regions (2009-2013)

\begin{tabular}{lccc}
\hline & Value & df & $\begin{array}{c}\text { Asymp.Sig. } \\
(2 \text {-sided })\end{array}$ \\
\hline Pearson Chi-Square & $230,340^{\mathrm{a}}$ & 20 & 0,000 \\
Likelihood Ratio & 226,004 & 20 & 0,000 \\
N of Valid Cases & 1851 & & \\
\hline
\end{tabular}

a. 5 cells $(16,7 \%)$ have expected count less than 5 . The minimum expected count is 2,00 .

The test result indicated that since the P-value $(0.00)$ is less than the significance level $(\alpha=0.05)$, The Null Hypothesis $\left(H_{0}\right)$ is Rejected, Alternative Hypothesis $\left(\mathrm{H}_{1}\right)$ is Accepted. The attacks by years and attacks as regions are not independent. Therefore, there is a statistical relationship exists between attacks by years and attacks by regions.

\subsubsection{The Chi-Square Test Between Attacks by Locations and Attacks by Years}

Most of these attacks occurred off the coast of Somalia with the frequency $435(23,5 \%)$ and respectively Indonesia with $306(16,5 \%)$, Gulf of Aden with $225(12,2 \%)$, Nigeria with $112(6,1 \%)$, Red Sea with $93(5,0 \%)$, Bangladesh $72(3,9 \%)$, Malaysia with $71(3,8 \%)$, Malacca and Singapure Sraits with $46(2,5 \%)$ in the period $2009-2013$ as shown in Table 3. Attacks in Gulf of Aden recorded 6 attacks in 2013, down from 12 in 2012. According to IMB PRC attacks have dropped significantly in Somalia which recorded 7 attacks in 2013, down from 49 in 2012 and 161 in 2011. Benin accounted for 29 of the 1851 attacks in 2009-2013 and no attack in 2013. Although the number of attacks have dropped significantly, these waters remain an area of concern (icc-ccs.org, 2015: $1)$. The attacks are continuing to increase in the waters of the Indonesia (105), Nigeria (30), India (14) and Vietnam (9) in 2013. The attacks off India have been increasing since 2009. Attacks have also dropped significantly in Malaysia (10) and Red Sea (2) in 2013 due to increased/active military action on suspected skiffs, military land based anti piracy operations, preventive measures such as BMP and increased maritime patrols and armed guards on board ships. Most of the these attacks in the Indonesian anchorages and Bangladesh waters remain lowlevel opportunistic thefts and should not be compared with the more serious attacks off Africa (IMB PRC Annual Report 2009 - 2013: 21-24). 
Table 3. Crosstabulation for Attacks by Locations and Attacks by Years (2009-2013)

\begin{tabular}{|c|c|c|c|c|c|c|c|}
\hline $\begin{array}{l}\text { Attacks by } \\
\text { locations/ } \\
\text { years }\end{array}$ & $\begin{array}{l}\text { Count } \\
\% \text { within } \\
\text { inc. by } \\
\text { loc. }\end{array}$ & 2009 & 2010 & 2011 & 2012 & 2013 & Total \\
\hline \multirow[t]{3}{*}{ Bangladesh } & Count & 16 & 23 & 10 & 11 & 12 & 72 \\
\hline & Expec. C. & 15,8 & 17,3 & 17,1 & 11,6 & 10,3 & 72,0 \\
\hline & $\%$ & 22,2 & 31,9 & 13,9 & 15,3 & 16,7 & 100,0 \\
\hline \multirow[t]{3}{*}{ Gulf of Aden } & Count & 117 & 53 & 37 & 12 & 6 & 225 \\
\hline & Expec. C. & 49,4 & 54,1 & 53,4 & 36,1 & 32,1 & 225,0 \\
\hline & $\%$ & 52,0 & 23,6 & 16,4 & 5,3 & 2,7 & 100,0 \\
\hline \multirow[t]{3}{*}{ Somalia } & Count & 80 & 138 & 161 & 49 & 7 & 435 \\
\hline & Expec. C. & 95,4 & 104,6 & 103,2 & 69,8 & 62,0 & 435,0 \\
\hline & $\%$ & 18,4 & 31,7 & 37,0 & 11,3 & 1,6 & 100,0 \\
\hline \multirow[t]{3}{*}{ Indonesia } & Count & 14 & 61 & 47 & 79 & 105 & 306 \\
\hline & Expec. C. & 67,1 & 73,6 & 72,6 & 49,1 & 43,6 & 306,0 \\
\hline & $\%$ & 4,6 & 19,9 & 15,4 & 25,8 & 34,3 & 100,0 \\
\hline \multirow[t]{3}{*}{ Malaysia } & Count & 17 & 17 & 15 & 12 & 10 & 71 \\
\hline & Expec. C. & 15,6 & 17,1 & 16,8 & 11,4 & 10,1 & 71,0 \\
\hline & $\%$ & 23,9 & 23,9 & 21,1 & 16,9 & 14,1 & 100,0 \\
\hline \multirow[t]{3}{*}{ Nigeria } & Count & 28 & 21 & 10 & 23 & 30 & 112 \\
\hline & Expec. C. & 24,6 & 26,9 & 26,6 & 18,0 & 16,0 & 112,0 \\
\hline & $\%$ & 25,0 & 18,8 & 8,9 & 20,5 & 26,8 & 100,0 \\
\hline \multirow[t]{3}{*}{ Tanzania } & Count & 4 & 1 & 0 & 2 & 1 & 8 \\
\hline & Expec. C. & 1,8 & 1,9 & 1,9 & 1,3 & 1,1 & 8,0 \\
\hline & $\%$ & 50,0 & 12,5 & 0,0 & 25,0 & 12,5 & 100,0 \\
\hline \multirow[t]{3}{*}{ Vietnam } & Count & 10 & 12 & 8 & 4 & 9 & 43 \\
\hline & Expec. C. & 9,4 & 10,3 & 10,2 & 6,9 & 6,1 & 43,0 \\
\hline & $\%$ & 23,3 & 27,9 & 18,6 & 9,3 & 20,9 & 100,0 \\
\hline \multirow[t]{3}{*}{ Malac./Sin.Str } & Count & 11 & 4 & 12 & 9 & 10 & 46 \\
\hline & Expec. C. & 10,1 & 11,1 & 10,9 & 7,4 & 6,6 & 46,0 \\
\hline & $\%$ & 23,9 & 8,7 & 26,1 & 19,6 & 21,7 & 100,0 \\
\hline \multirow[t]{3}{*}{ S. China Sea } & Count & 12 & 12 & 14 & 3 & 4 & 45 \\
\hline & Expec. C. & 9,9 & 10,8 & 10,7 & 7,2 & 6,4 & 45,0 \\
\hline & $\%$ & 26,7 & 26,7 & 31,1 & 6,7 & 8,9 & 100,0 \\
\hline \multirow[t]{3}{*}{ India } & Count & 0 & 5 & 6 & 8 & 14 & 33 \\
\hline & Expec. C. & 7,2 & 7,9 & 7,8 & 5,3 & 4,7 & 33,0 \\
\hline & $\%$ & 0,0 & 15,2 & 18,2 & 24,2 & 42,4 & 100,0 \\
\hline \multirow[t]{3}{*}{ Red Sea } & Count & 14 & 24 & 38 & 15 & 2 & 93 \\
\hline & Expec. C. & 20,4 & 22,4 & 22,1 & 14,9 & 13,3 & 93,0 \\
\hline & $\%$ & 15,1 & 25,8 & 40,9 & 16,1 & 2,2 & 100,0 \\
\hline \multirow[t]{3}{*}{ Benin } & Count & 2 & 0 & 23 & 4 & 0 & 29 \\
\hline & Expec. C. & 6,4 & 7,0 & 6,9 & 4,7 & 4,1 & 29,0 \\
\hline & $\%$ & 6,9 & 0,0 & 79,3 & 13,8 & 0,0 & 100,0 \\
\hline \multirow[t]{3}{*}{ Others } & Count & 81 & 74 & 58 & 66 & 54 & 333 \\
\hline & Expec. C. & 73,0 & 80,1 & 79,0 & 53,4 & 47,5 & 333,0 \\
\hline & $\%$ & 24,3 & 22,2 & 17,4 & 19,8 & 16,2 & 100,0 \\
\hline \multirow[t]{3}{*}{ Total } & Count & 406 & 445 & 439 & 297 & 264 & 1851 \\
\hline & Expec. C. & 406,0 & 445,0 & 439,0 & 297,0 & 264,0 & 1851,0 \\
\hline & $\%$ & 21,9 & 24,0 & 23,7 & 16,0 & 14,3 & 100,0 \\
\hline
\end{tabular}

Source: ICC, IMB Piracy and Armed Robbery Against Ships Annual Reports 2009-2013. 
The Pearson Chi Square value is 559,926 as shown in Table 4. The samples are simple random samples; all individual expected counts are more than 1 and $11,4 \%$ of expected counts are less than 5 . The minimum expected count is more than $1(1,14)$. The sample size requirement for the chi-square test of independence is satisfied. Therefore, The Chi Square is used.

Hypothesis;

$\mathrm{H}_{0}$ : The attacks by locations and attacks by years are independent

$\mathrm{H}_{1}$ : The attacks by locations and attacks by years are not independent

Table 4. The Chi-Square Test Between Attacks by Locations and Attacks by Years (2009-2013)

\begin{tabular}{lccc}
\hline & Value & df & $\begin{array}{c}\text { Asymp.Sig. } \\
(2 \text {-sided })\end{array}$ \\
\hline Pearson Chi-Square & $559,926^{\text {a }}$ & 52 & 0,000 \\
Likelihood Ratio & 577,698 & 52 & 0,000 \\
N of Valid Cases & 1851 & & \\
\hline
\end{tabular}

a. 8 cells $(11,4 \%)$ have expected count less than 5 . The minimum expected count is 1,14 .

$\mathrm{H}_{0}$ is rejected, $\mathrm{H}_{1}$ is accepted $(\mathrm{P}=0.00<\alpha=0.05)$. The attacks by locations and attacks by years are not independent. Therefore, there is a statistical relationship exists between the two variables.

\subsubsection{The Chi-Square Test Between Attacks by Years and Type of Attacks}

Globally, 187 vessels were hijacked (10\%), 902 (48,7\%) boarded, 388 fired upon $(21,0 \%)$ and further $374(20,2 \%)$ reported attempted attacks in the period of 2009-2013 as shown in Table 5. The attacks have dropped significantly due to preventive measurements, antipiracy operations and armed guards on board ships. 
Table 5. Crosstabulation for Attacks by Years and Type of Attacks (2009-2013)

\begin{tabular}{|c|c|c|c|c|c|c|}
\hline \multicolumn{1}{|c|}{} & \multicolumn{3}{|c|}{ Type of Attacks } & \\
\hline Years & $\begin{array}{c}\text { Count } \\
\text { \% within } \\
\text { years of } \\
\text { attacks }\end{array}$ & Attempted & $\begin{array}{c}\text { Fired } \\
\text { upon }\end{array}$ & Hijack & Boarded & Total \\
\hline \multirow{4}{*}{2009} & Count & 85 & 119 & 49 & 153 & 406 \\
\cline { 2 - 7 } & Expec.C. & 82,0 & 85,1 & 41,0 & 197,8 & 406,0 \\
\cline { 2 - 7 } & $\%$ & 20,9 & 29,3 & 12,1 & 37,7 & 100,0 \\
\hline \multirow{3}{*}{2010} & Count & 89 & 106 & 53 & 197 & 445 \\
\cline { 2 - 7 } & Expec.C. & 89,9 & 93,3 & 45,0 & 216,9 & 445,0 \\
\cline { 2 - 7 } & $\%$ & 20,0 & 23,8 & 11,9 & 44,3 & 100,0 \\
\hline & Count & 105 & 113 & 45 & 176 & 439 \\
\cline { 2 - 7 } & Expec.C. & 88,7 & 92,0 & 44,4 & 213,9 & 439,0 \\
\cline { 2 - 7 } & $\%$ & 23,9 & 25,7 & 10,3 & 40,1 & 100,0 \\
\hline & Count & 67 & 28 & 28 & 174 & 297 \\
\cline { 2 - 7 } & Expec.C. & 60,0 & 62,3 & 30,0 & 144,7 & 297,0 \\
\cline { 2 - 7 } & $\%$ & 22,6 & 9,4 & 9,4 & 58,6 & 100,0 \\
\hline \multirow{3}{*}{2013} & Count & 28 & 22 & 12 & 202 & 264 \\
\cline { 2 - 7 } & Expec.C. & 53,3 & 55,3 & 26,7 & 128,6 & 264,0 \\
\cline { 2 - 7 } & $\%$ & 10,6 & 8,3 & 4,5 & 76,5 & 100,0 \\
\hline \multirow{3}{*}{ Total } & Count & 374 & 388 & 187 & 902 & 1851 \\
\cline { 2 - 7 } & Expec.C. & 374,0 & 388,0 & 187,0 & 902,0 & 1851,0 \\
\cline { 2 - 7 } & $\%$ & 20,2 & 21,0 & 10,1 & 48,7 & 100,0 \\
\hline
\end{tabular}

Source: ICC, IMB Piracy and Armed Robbery Against Ships Annual Reports 2009-2013

The Pearson Chi Square value is 152,572 as shown in Table 6. The samples are simple random samples; all individual expected counts are more than 1 and $0,0 \%$ of expected counts are less than 5 . The minimum expected count is more than $1(26,67)$. The sample size requirement for the chi-square test of independence is satisfied. Therefore, The Chi Square is used.

Hypothesis;

$\mathrm{H}_{0}$ : The attacks by years and type of attacks are independent $\mathrm{H}_{1}$ : The attacks by years and type of attacks are not independent

Table 6. Chi-Square Test Between Attacks by Years and Type of Attacks (2009-2013)

\begin{tabular}{lccc}
\hline & Value & df & $\begin{array}{c}\text { Asymp.Sig. } \\
\text { (2-sided) }\end{array}$ \\
\hline Pearson Chi-Square & $152,572^{\mathrm{a}}$ & 12 & 0,00 \\
Likelihood Ratio & 160,631 & 12 & 0,00 \\
N of Valid Cases & 1851 & & \\
\hline
\end{tabular}

a. 0 cells $(0,0 \%)$ have expected count less than 5 . The minimum expected count is 26,67 . 
$\mathrm{H}_{0}$ is rejected, $\mathrm{H}_{1}$ is Accepted $(\mathrm{P}=0.00<\alpha=0.05)$. The attacks by years and type of attacks are not independent. Therefore, there is a statistical relationship exists between the two variables.

\subsubsection{The Chi-Square Test Between Type of Attacks and Attacks by Regions}

The most attack occurred was fired upon (383) and respectively attempted (270), boarded (225) and hijacked (166) in Africa in the period of 2009-2013 as shown in Table 7. The most attack occurred was boarded (362) and respectively attempted (52) and hijack (14) in South East Asia in this period. The most attack occurred was boarded in Indian Subcontinent (107), boarded in Americas (113) and also boarded in Far East (91) in the period. The number of crew taken hostage stands at 3915, 33 crew member was killed, 197 insured, 9 missing and 111 kidnapped/ransom in the period of 2009-2013. The number of people taken hostage onboard fell to 304 in 2013 from 1050 in 2009.

Table 7. Crosstabulation for Type of Attacks and Attacks by Regions (2009 - 2013)

\begin{tabular}{|c|c|c|c|c|c|c|c|c|}
\hline \multirow[b]{2}{*}{$\begin{array}{l}\text { Type of } \\
\text { attacks }\end{array}$} & \multirow[b]{2}{*}{$\begin{array}{c}\text { Count } \\
\% \\
\text { within } \\
\text { type of } \\
\text { attacks }\end{array}$} & \multicolumn{6}{|c|}{ Attacks by regions } & \multirow[b]{2}{*}{ Tot. } \\
\hline & & Africa & $\begin{array}{l}\text { S. East } \\
\text { Asia }\end{array}$ & $\begin{array}{c}\text { Indian } \\
\text { Sub } \\
\text { Cont. }\end{array}$ & $\begin{array}{c}\text { Ameri } \\
\text { cas }\end{array}$ & $\begin{array}{l}\text { Far } \\
\text { East }\end{array}$ & Oth. & \\
\hline \multirow[t]{3}{*}{ Attempted } & Count & 270 & 52 & 11 & 24 & 11 & 6 & 374 \\
\hline & Expec.C & 210,9 & 86,5 & 23,8 & 27,7 & 22,2 & 2,8 & 374,0 \\
\hline & $\%$ & 72,2 & 13,9 & 2,9 & 6,4 & 2,9 & 1,6 & 100,0 \\
\hline \multirow{3}{*}{ Fired Upon } & Count & 383 & 0 & 0 & 0 & 3 & 2 & 388 \\
\hline & Expec.C & 218,8 & 89,7 & 24,7 & 28,7 & 23,1 & 2,9 & 388,0 \\
\hline & $\%$ & 98,7 & 0,0 & 0,0 & 0,0 & 0,8 & 0,5 & 100,0 \\
\hline \multirow[t]{3}{*}{ Hijack } & Count & 166 & 14 & 0 & 0 & 5 & 2 & 187 \\
\hline & Expec.C & 105,5 & 43,2 & 11,9 & 13,8 & 11,1 & 1,4 & 187,0 \\
\hline & $\%$ & 88,8 & 7,5 & 0,0 & 0,0 & 2,7 & 1,1 & 100,0 \\
\hline \multirow[t]{3}{*}{ Boarded } & Count & 225 & 362 & 107 & 113 & 91 & 4 & 902 \\
\hline & Expec.C & 508,7 & 208,6 & 57,5 & 66,8 & 53,6 & 6,8 & 902,0 \\
\hline & $\%$ & 24,9 & 40,1 & 11,9 & 12,5 & 10,1 & 0,4 & 100,0 \\
\hline \multirow[t]{3}{*}{ Total } & Count & 1044 & 428 & 118 & 137 & 110 & 14 & 1851 \\
\hline & Expec.C & 1044,0 & 428,0 & 118,0 & 137,0 & 110,0 & 14,0 & 1851,0 \\
\hline & $\%$ & 56,4 & 23,1 & 6,4 & 7,4 & 5,9 & 0,8 & 100,0 \\
\hline
\end{tabular}

Source: ICC, IMB Piracy and Armed Robbery Against Ships Annual

Reports 2009-2013. 
According to the result of Chi Square Test, the samples are simple random samples; all individual expected counts are more than 1 and $12,5 \%$ of expected counts are less than 5 as shown in Table 8 . The Chi Square value is 787,867 . The minimum expected count is more than $1(1,41)$. Therefore, the sample size requirement for the chi-square test of independence is satisfied. Therefore, The Chi Square is used.

Hypothesis;

$\mathrm{H}_{0}$ : The type of attacks and attacks by regions are independent

$\mathrm{H}_{1}$ : The type of attacks and attacks by regions are not independent

Table 8. Chi-Square Test Between Type of Attacks and Attacks by Regions (2009 - 2013)

\begin{tabular}{lccc}
\hline & Value & df & $\begin{array}{c}\text { Asymp.Sig. } \\
(2 \text {-sided })\end{array}$ \\
\hline Pearson Chi-Square & $787,867^{\text {a }}$ & 15 & 0,00 \\
Likelihood Ratio & 953,388 & 15 & 0,00 \\
N of Valid Cases & 1851 & & \\
\hline
\end{tabular}

a. 3 cells $(12,5 \%)$ have expected count less than 5 . The minimum expected count is 1,41 .

$\mathrm{H}_{0}$ is rejected, $\mathrm{H}_{1}$ is accepted $(\mathrm{P}=0.00<\alpha=0.05)$. The type of attacks and attacks by regions are not independent. Therefore, there is a statistical relationship exists between the two variables.

\subsubsection{The Chi-Square Test Between Attacks by Months and Attacks by Regions}

Most of these attacks occurred between March and May (574) and respectively between December and February (444), September and November (427) and June and August (405) in the period of 2009-2013 as shown in Table 9. Most of these attacks occurred in Africa and Far East between March and May, in South East Asia between December and May, Indian Sub Continent between September and November and in Americas between December and February in this period. 
Table 9. Crosstabulation for Attacks by Months and Attacks by Regions (2009-2013)

\begin{tabular}{|c|c|c|c|c|c|c|c|c|}
\hline \multirow{2}{*}{$\begin{array}{l}\text { Attacks } \\
\text { by } \\
\text { months }\end{array}$} & & \multicolumn{6}{|c|}{ Attacks by regions } & \multirow[b]{2}{*}{ Total } \\
\hline & & Africa & $\begin{array}{c}\text { S. } \\
\text { East } \\
\text { Asia }\end{array}$ & $\begin{array}{c}\text { Indian } \\
\text { Sub } \\
\text { Cont. }\end{array}$ & Americas & $\begin{array}{l}\text { Far } \\
\text { East }\end{array}$ & Other & \\
\hline \multirow{3}{*}{$\begin{array}{c}\text { Dec - Jan } \\
- \text { Feb }\end{array}$} & Count & 246 & 110 & 26 & 43 & 17 & 2 & 444 \\
\hline & $\begin{array}{c}\text { Expected } \\
\text { Count }\end{array}$ & 250,4 & 102,7 & 28,3 & 32,9 & 26,4 & 3,4 & 444,0 \\
\hline & $\begin{array}{c}\% \text { within } \\
\text { type of } \\
\text { attacks }\end{array}$ & 55,4 & 24,8 & 5,9 & 9,7 & 3,8 & 0,5 & 100,0 \\
\hline \multirow{3}{*}{$\begin{array}{c}\text { March - } \\
\text { Apr. - } \\
\text { May }\end{array}$} & Count & 367 & 110 & 23 & 30 & 40 & 4 & 574 \\
\hline & $\begin{array}{c}\text { Expected } \\
\text { Count }\end{array}$ & 323,7 & 132,7 & 36,6 & 42,5 & 34,1 & 4,3 & 574,0 \\
\hline & $\begin{array}{c}\% \text { within } \\
\text { type of } \\
\text { attacks }\end{array}$ & 63,9 & 19,2 & 4,0 & 5,2 & 7,0 & 0,7 & 100,0 \\
\hline \multirow{3}{*}{$\begin{array}{c}\text { Jun-July } \\
\text {-Aug. }\end{array}$} & Count & 217 & 91 & 30 & 29 & 32 & 6 & 405 \\
\hline & $\begin{array}{c}\text { Expected } \\
\text { Count }\end{array}$ & 228,4 & 93,6 & 25,8 & 30,0 & 24,1 & 3,1 & 405,0 \\
\hline & $\begin{array}{c}\% \text { within } \\
\text { type of } \\
\text { attacks }\end{array}$ & 53,6 & 22,5 & 7,4 & 7,2 & 7,9 & 1,5 & 100,0 \\
\hline \multirow{3}{*}{$\begin{array}{l}\text { Sep.-Oct. } \\
\text {-Nov. }\end{array}$} & Count & 214 & 116 & 39 & 35 & 21 & 2 & 427 \\
\hline & $\begin{array}{c}\text { Expected } \\
\text { Count }\end{array}$ & 240,8 & 98,7 & 27,2 & 31,6 & 25,4 & 3,2 & 427,0 \\
\hline & $\begin{array}{c}\% \text { within } \\
\text { type of } \\
\text { attacks }\end{array}$ & 50,1 & 27,2 & 9,1 & 8,2 & 4,9 & 0,5 & 100,0 \\
\hline \multirow{3}{*}{ Total } & Count & 1044 & 427 & 118 & 137 & 110 & 14 & 1851 \\
\hline & $\begin{array}{c}\text { Expected } \\
\text { Count }\end{array}$ & 1044,0 & 428,0 & 118,0 & 137,0 & 110,0 & 14,0 & 1851,0 \\
\hline & $\begin{array}{c}\% \text { within } \\
\text { type of } \\
\text { attacks }\end{array}$ & 56,4 & 23,1 & 6,4 & 7,4 & 5,9 & 0,8 & 100,0 \\
\hline
\end{tabular}

Source: ICC, IMB Piracy and Armed Robbery Against Ships Annual Reports 2009-2013.

According to the result of Chi Square Test, the samples are simple random samples; all individual expected counts are more than 1 and $16,7 \%$ of expected counts are less than 5 . The Chi Square value is 46,705 as shown in Table 10. The minimum expected count is more than $1(3,06)$. Therefore, the sample size requirement for the chi-square test of independence is satisfied. Therefore, The Chi Square is used. 
According to the result of Chi Square Test, the samples are simple random samples; all individual expected counts are more than 1

Hypothesis;

$\mathrm{H}_{0}$ : The attacks by months and attacks by regions are independent.

$\mathrm{H}_{1}$ : The attacks by months and attacks by regions are not independent.

Table 10. Chi-Square Test Between Attacks by Months and Attacks by Regions (2009-2013)

\begin{tabular}{lccc}
\hline & Value & df & $\begin{array}{c}\text { Asymp.Sig. } \\
(2-\text {-sided })\end{array}$ \\
\hline Pearson Chi-Square & $46,705^{\text {a }}$ & 15 & 0,000 \\
Likelihood Ratio & 46,720 & 15 & 0,000 \\
N of Valid Cases & 1851 & & \\
\hline
\end{tabular}

a. 4 cells $(16,7 \%)$ have expected count less than 5 . The minimum expected count is 3,06 .

$\mathrm{H}_{0}$ is rejected, $\mathrm{H}_{1}$ is accepted $(\mathrm{P}=0.00<\alpha=0.05)$. The attacks by months and attacks by regions are not independent. Therefore, there is a statistical relationship exists between the two variables.

\subsubsection{The Chi-Square Test Between Hours of Attacks and Type of Attacks}

Most of these attacks occurred the hours between 24:01 - 04:00 (581 attacks) and respectively between 04:01 - 08:00 (376), 20:00 -24:00 (280), 12:00 - 16:00 (233), 08:01 - 12:00 (192) and 16:01 -20:00 (135) in $2009-2013$ as shown in Table 11.

In the analyze, Local Time (LT) is used for the regions such as South East Asia, Indian Sub-Continent, Americas Far East and Africa except Gulf of Aden and Somalia, Coordinated Universal Time (UTC) is used for the region Gulf of Aden and Somalia for for actual attacks. Local Time (LT) is also used for the regions such as South East Asia, Indian Sub-Continent, Americas, Far East and UTC is used for Africa for attempted attacks. 
Table 11. Crosstabulation for Hours Of Attacks and Type of Attacks (2009-2013)

\begin{tabular}{|c|c|c|c|c|c|c|}
\hline & & & Type of & tacks & & \\
\hline $\begin{array}{l}\text { Hours of } \\
\text { attacks }\end{array}$ & $\begin{array}{c}\text { Count } \\
\% \text { within } \\
\text { hours of } \\
\text { attacks }\end{array}$ & Attempted & $\begin{array}{l}\text { Fired } \\
\text { upon }\end{array}$ & Hijack & Boarded & Total \\
\hline $\mathrm{NA}$ & Count & 1 & 0 & 34 & 19 & 54 \\
\hline & Excep. C & 10,9 & 11,3 & 5,5 & 26,3 & 54,0 \\
\hline & $\%$ & 1,9 & 0,0 & 63,0 & 35,2 & 100,0 \\
\hline $24: 01-04: 00$ & Count & 73 & 64 & 40 & 404 & 581 \\
\hline & Excep. C & 117,4 & 121,8 & 58,7 & 283,1 & 581,0 \\
\hline & $\%$ & 12,6 & 11,0 & 6,9 & 69,5 & 100,0 \\
\hline 04:01-08:00 & Count & 107 & 89 & 44 & 136 & 376 \\
\hline & Excep. C & 76,0 & 78,8 & 38,0 & 183,2 & 376,0 \\
\hline & $\%$ & 28,5 & 23,7 & 11,7 & 36,2 & 100,0 \\
\hline 08:01-12:00 & Count & 53 & 90 & 19 & 30 & 192 \\
\hline & Excep. C & 38,8 & 40,2 & 19,4 & 93,6 & 192,0 \\
\hline & $\%$ & 27,6 & 46,9 & 9,9 & 15,6 & 100,0 \\
\hline $12: 01-16: 00$ & Count & 73 & 80 & 28 & 52 & 233 \\
\hline & Excep. C & 47,1 & 48,8 & 23,5 & 113,5 & 233,0 \\
\hline & $\%$ & 31,3 & 34,3 & 12,0 & 22,3 & 100,0 \\
\hline $16: 01-20: 00$ & Count & 26 & 33 & 8 & 68 & 135 \\
\hline & Excep. C & 27,3 & 28,3 & 13,6 & 65,8 & 135,0 \\
\hline & $\%$ & 19,3 & 24,4 & 5,9 & 50,4 & 100,0 \\
\hline $20: 01-24: 00$ & Count & 41 & 32 & 14 & 193 & 280 \\
\hline & Excep. C & 56,6 & 58,7 & 28,3 & 136,4 & 280,0 \\
\hline & $\%$ & 14,6 & 11,4 & 5,0 & 68,9 & 100,0 \\
\hline Total & Count & 374 & 388 & 187 & 902 & 1851 \\
\hline & Excep. C & 374,0 & 388,0 & 187,0 & 902,0 & 1851,0 \\
\hline & $\%$ & 20,2 & 21,0 & 10,1 & 48,7 & 100,0 \\
\hline
\end{tabular}

Source: ICC, IMB Piracy and Armed Robbery Against Ships Annual Reports 2009-2013.

The Pearson Chi Square value is 529,175 as shown in Table 12 . The samples are simple random samples; all individual expected counts are more than 1 and $0,0 \%$ of expected counts are less than 5 . The minimum expected count is more than $1(5,46)$. The sample size requirement for the chi-square test of independence is satisfied. Therefore, The Chi Square is used. 
Hypothesis;

$\mathrm{H}_{0}$ : The hours of attacks and type of attacks are independent

$\mathrm{H}_{1}$ : The hours of attacks and type of attacks are not independent

Table 12. The Chi-Square Test Between Hours of Attacks and Type of Attacks (2009-2013)

\begin{tabular}{lccc}
\hline & Value & df & $\begin{array}{c}\text { Asymp.Sig. } \\
(2-\text {-sided })\end{array}$ \\
\hline Pearson Chi-Square & $529,175^{\mathrm{a}}$ & 18 & 0,000 \\
Likelihood Ratio & 471,875 & 18 & 0,000 \\
N of Valid Cases & 1851 & & \\
\hline
\end{tabular}

a. 0 cells $(0,0 \%)$ have expected count less than 5 . The minimum expected count is 5,46 .

$\mathrm{H}_{0}$ is rejected, $\mathrm{H}_{1}$ is accepted $(\mathrm{P}=0.00<\alpha=0.05)$. The hours of attacks and type of attacks are not independent. Therefore, there is a statistical relationship exists between two variables.

\subsubsection{The Chi-Square Test Between Type of Ships Attacked and Type of Attacks}

The ships most commonly attacked were bulk carriers (407) and respectively chemical tanker (288), container (266), tanker (230), general cargo (184) and product tanker (134) in the period of 2009-2013 as shown in Table 13.

Table 13. Crosstabulation for type of Ships Attacked and Type of Attacks (2009-2013)

\begin{tabular}{|c|c|c|c|c|c|c|}
\hline & \multicolumn{5}{|c|}{ Type of attacks } & \multirow[b]{2}{*}{ Total } \\
\hline Type of ships & $\begin{array}{l}\text { Count } \\
\% \text { within } \\
\text { type of } \\
\text { ships }\end{array}$ & Attempted & $\begin{array}{l}\text { Fired } \\
\text { upon }\end{array}$ & Hijack & Boarded & \\
\hline \multirow[t]{2}{*}{$\mathrm{NA}$} & Count & 0 & 1 & 2 & 1 & 4 \\
\hline & $\%$ & 0,0 & 25,0 & 50,0 & 25,0 & 100,0 \\
\hline \multirow{2}{*}{ Fishing vessels } & Count & 6 & 13 & 32 & 4 & 55 \\
\hline & $\%$ & 10,9 & 23,6 & 58,2 & 7,3 & 100,0 \\
\hline \multirow[t]{2}{*}{ General Cargo } & Count & 42 & 41 & 22 & 79 & 184 \\
\hline & $\%$ & 22,8 & 22,3 & 12,0 & 42,9 & 100,0 \\
\hline \multirow[t]{2}{*}{ Bulk carrier } & Count & 82 & 98 & 26 & 201 & 407 \\
\hline & $\%$ & 20,1 & 24,1 & 6,4 & 49,4 & 100,0 \\
\hline \multirow[t]{2}{*}{ Container } & Count & 58 & 54 & 5 & 149 & 266 \\
\hline & $\%$ & 21,8 & 20,3 & 1,9 & 56,0 & 100,0 \\
\hline \multirow[t]{2}{*}{ Tanker } & Count & 63 & 67 & 9 & 91 & 230 \\
\hline & $\%$ & 27,4 & 29,1 & 3,9 & 39,6 & 100,0 \\
\hline
\end{tabular}


Table 13. Crosstabulation for type of Ships Attacked and Type of Attacks (2009-2013) (Continued)

\begin{tabular}{|c|c|c|c|c|c|c|}
\hline \multirow{3}{*}{$\begin{array}{l}\text { Chemical } \\
\text { tanker }\end{array}$} & \multicolumn{5}{|c|}{ Type of attacks } & \multirow[b]{2}{*}{288} \\
\hline & Count & 74 & 45 & 32 & 137 & \\
\hline & $\%$ & 25,7 & 15,6 & 11,1 & 47,6 & 100,0 \\
\hline \multirow[t]{2}{*}{ Product tanker } & Count & 17 & 31 & 18 & 68 & 134 \\
\hline & $\%$ & 12,7 & 23,1 & 13,4 & 50,7 & 100,0 \\
\hline \multirow{2}{*}{$\begin{array}{l}\text { LPG-LNG } \\
\text { Tanker }\end{array}$} & Count & 5 & 10 & 2 & 23 & 40 \\
\hline & $\%$ & 12,5 & 25,0 & 5,0 & 57,5 & 100,0 \\
\hline \multirow[b]{2}{*}{ Refrigerate ves. } & Count & 1 & 0 & 2 & 13 & 16 \\
\hline & $\%$ & $6,3 \%$ & $0,0 \%$ & $12,5 \%$ & $81,3 \%$ & $100,0 \%$ \\
\hline \multirow{2}{*}{$\begin{array}{l}\text { Vehicle carrier- } \\
\mathrm{R}_{\mathrm{g}} \mathrm{R}_{\mathrm{g}}\end{array}$} & Count & 9 & 10 & 3 & 14 & 36 \\
\hline & $\%$ & $25,0 \%$ & $27,8 \%$ & $8,3 \%$ & $38,9 \%$ & $100,0 \%$ \\
\hline \multirow[t]{2}{*}{ Yatch } & Count & 0 & 1 & 8 & 5 & 14 \\
\hline & $\%$ & $0,0 \%$ & $7,1 \%$ & $57,1 \%$ & $35,7 \%$ & $100,0 \%$ \\
\hline \multirow[t]{2}{*}{ Tug } & Count & 8 & 2 & 13 & 83 & 106 \\
\hline & $\%$ & $7,5 \%$ & $1,9 \%$ & $12,3 \%$ & $78,3 \%$ & $100,0 \%$ \\
\hline \multirow[t]{2}{*}{ Others } & Count & 9 & 15 & 13 & 34 & 71 \\
\hline & $\%$ & $12,7 \%$ & $21,1 \%$ & $18,3 \%$ & $47,9 \%$ & $100,0 \%$ \\
\hline \multirow[t]{2}{*}{ Total } & Count & 374 & 388 & 187 & 902 & 1851 \\
\hline & $\%$ & $20,2 \%$ & $21.0 \%$ & $10.1 \%$ & $48.7 \%$ & $100,0 \%$ \\
\hline
\end{tabular}

Source: ICC, IMB Piracy and Armed Robbery Against Ships Annual Reports 2009-2013.

According to the result of Chi Square Test, the samples are simple random samples; all individual expected counts are not more than 1. No more than $20 \%$ of expected counts are less than 5 to use Chi Square Test. As shown Table 14, 21,4\% of expected counts are less than 5. The Chi Square value is 328,685 .

Table 14. Chi-Square Test Between Type of Ships Attacked and Type of Attacks (2009-2013)

\begin{tabular}{lccc} 
& Value & df & $\begin{array}{c}\text { Asymp.Sig. } \\
(2-\text {-sided })\end{array}$ \\
\hline Pearson Chi-Square & $328,685^{\text {a }}$ & 39 & 0,00 \\
Likelihood Ratio & 285,332 & 39 & 0,00 \\
N of Valid Cases & 1851 & & \\
\hline
\end{tabular}

a. 12 cells $(21,4 \%)$ have expected count less than 5 . The minimum expected count is 0,40 .

According to the result of Chi Square Test in Table 14, the minimum expected count is not more than $1(0,40)$. The sample size requirement for the chi-square test of independence is not satisfied. In 
this case, the Chi Square is not significant supports the hypothesis. Therefore, it is combined the rows which give type of ships such as fishing vessels, general cargo, bulk carrier, container, tanker, RoRo\&vehicles and others. The result of Chi Square Test of combined table is given in Table 15 .

Table 15. Chi-Square Test Between Type of Ships Attacked and Type of Attacks (2009 - 2013)

\begin{tabular}{lllc} 
& Value & df & $\begin{array}{c}\text { Asymp.Sig. } \\
(2 \text {-sided) }\end{array}$ \\
\hline Pearson Chi-Square & $226.587^{\mathrm{a}}$ & 18 & 0,000 \\
Likelihood Ratio & 183,968 & 18 & 0,000 \\
N of Valid Cases & 1851 & & \\
\hline
\end{tabular}

1 cells $(3,6 \%)$ have expected count less than 5 . The minimum expected count is 3,43 .

According to the result of Chi Square Test, all individual expected counts are more than 1,3,6\% of expected counts are less than 5, the minimum expected count is more than $1(3,43)$. The Chi Square value is 226.587 as shown in Table 15. The sample size requirement for the chi-square test of independence is satisfied. Therefore, the Chi Square is t used to analyze the relationship between type of ships attacked and type of attacks.

Hypothesis;

$\mathrm{H}_{0}$ : The type of ships attacked and type of attacks are independent

$\mathrm{H}_{1}$ : The type of ships attacked and type of attacks are not independent

$\mathrm{H}_{0}$ is rejected, $\mathrm{H}_{1}$ is accepted $(\mathrm{P}=0.00<\alpha=0.05)$. The type of ships attacked and type of attacks are not independent. Therefore, there is a statistical relationship exists between the two variables.

\subsubsection{The Chi-Square Test Between Type of Attacks and Latitude and Longitude of Attacks}

The vessels most commonly were attacked in NE (01 - 49:00 - 59 N / 02 - 120:00 - 58 E) (1260 attacks) and respectively SE (00 - 27:00 $59 \mathrm{~S} / 11$ - 117:01 - 117) (285 attacks), NW (02 - 18:14 - 58 N / 00 83:01 - 59 W) (96 attacks) and SW (01 - 21:00 - 46 S /08 - 81:09 - 59 W) (52 attacks) as shown in Table 16. 
Table 16. Crosstabulation for Type of Attacks and Latitude and Longitude of Attacks (2009-2013)

\begin{tabular}{|c|c|c|c|c|c|c|c|}
\hline $\begin{array}{l}\text { Type of } \\
\text { attacks/ } \\
\text { Lat.and } \\
\text { Long of } \\
\text { Attacks. }\end{array}$ & $\begin{array}{c}\text { Count } \\
\% \text { within } \\
\text { type of } \\
\text { attacks }\end{array}$ & NA & N-E & N-W & S-E & S-W & Total \\
\hline \multirow[t]{3}{*}{ Attempted } & Count & 13 & 301 & 18 & 38 & 4 & 374 \\
\hline & Expect.C. & 31,9 & 254,6 & 19,4 & 57,6 & 10,5 & 374,0 \\
\hline & $\%$ & 3,5 & 80,5 & 4,8 & 10,2 & $1,1 \%$ & 100,0 \\
\hline \multirow{3}{*}{$\begin{array}{l}\text { Fired } \\
\text { Upon }\end{array}$} & Count & 0 & 306 & 4 & 78 & 0 & 388 \\
\hline & Expect.C & 33,1 & 264,1 & 20,1 & 59,7 & 10,9 & 388,0 \\
\hline & $\%$ & 0,0 & 78,9 & 1,0 & 20,1 & 0,0 & 100,0 \\
\hline \multirow[t]{3}{*}{ Hijack } & Count & 25 & 129 & 2 & 31 & 0 & 187 \\
\hline & Expect.C & 16,0 & 127,3 & 9,7 & 28,8 & 5,3 & 187,0 \\
\hline & $\%$ & 13,4 & 69,0 & 1,1 & 16,6 & 0,0 & 100,0 \\
\hline \multirow[t]{3}{*}{ Boarded } & Count & 120 & 524 & 72 & 138 & 48 & 902 \\
\hline & Expect.C & 77,0 & 614,0 & 46,8 & 138,9 & 25,3 & 902,0 \\
\hline & $\%$ & 13,3 & 58,1 & 8,0 & 15,3 & 5,3 & 100,0 \\
\hline \multirow[t]{3}{*}{ Total } & Count & 158 & 1260 & 96 & 285 & 52 & 1851 \\
\hline & Expect.C & 158,0 & 1260,0 & 96,0 & 285,0 & 52,0 & 1851,0 \\
\hline & $\%$ & 8,5 & 68,1 & 5,2 & 15,4 & 2,8 & 100,0 \\
\hline
\end{tabular}

Source: ICC, IMB Piracy and Armed Robbery Against Ships Annual Reports 2009-2013

The Pearson Chi Square value is 187,384 as shown in Table 17. The samples are simple random samples; all individual expected counts are more than 1 and $0,0 \%$ of expected counts are less than 5 . The minimum expected count is more than $1(5,25)$. The sample size requirement for the chi-square test of independence is satisfied. Therefore, The Chi Square is used.

Hypothesis;

$\mathrm{H}_{0}$ : The type of attacks and latitude and longitude of attacks are independent.

$\mathrm{H}_{1}$ : The type of attacks and latitude and longitude of attacks are not independent 
Table 17. Chi-Square Test Between Type of Attacks and Latitude and Longitude of Attacks (2009 - 2013)

\begin{tabular}{lccc}
\hline & Value & df & $\begin{array}{c}\text { Asymp.Sig. } \\
(2-\text {-sided })\end{array}$ \\
\hline Pearson Chi-Square & $187,384^{\mathrm{a}}$ & 12 & 0,000 \\
Likelihood Ratio & 240,391 & 12 & 0,000 \\
N of Valid Cases & 1851 & & \\
\hline
\end{tabular}

a. 0 cells $(0,0 \%)$ have expected count less than 5 . The minimum expected count is 5,25 .

$\mathrm{H}_{0}$ is rejected, $\mathrm{H}_{1}$ is accepted $(\mathrm{P}=0.00<\alpha=0.05)$. The type of attacks and latitude and longitude of attacks are not independent. Therefore, there is a statistical relationship exist between the type of attacks and latitude and longitude of attacks.

\subsubsection{The Chi-Square Test Between Number of Pirates Who Attacked and Type of Attacks}

Attempted, fired upon and boarded incidents mostly occurred by $4-6$ pirates and hijack mostly occurred by $10-12$ pirates in the period of $2009-2013$ as shown in Table 18.

Table 18. Crosstabulation for Number of Pirates Who Attacked and Type of Attacks (2009 - 2013)

\begin{tabular}{|l|c|c|c|c|c|c|}
\hline \multicolumn{2}{|c|}{} & \multicolumn{4}{|c|}{ Type of attacks } & \\
\hline $\begin{array}{l}\text { Number of } \\
\text { pirates } \\
\text { who } \\
\text { attacked }\end{array}$ & $\begin{array}{c}\text { Count } \\
\text { \% within } \\
\text { hours of } \\
\text { attacks }\end{array}$ & Attempted & $\begin{array}{l}\text { Fired } \\
\text { upon }\end{array}$ & Hijack & Boarded & Total \\
\hline \multirow{4}{*}{ NA } & Count & 192 & 216 & 153 & 390 & 951 \\
\cline { 2 - 7 } & Expect. C. & 192,2 & 199,3 & 96,1 & 463,4 & 951,0 \\
\cline { 2 - 7 } & $\%$ & 20,2 & 22,7 & 16,1 & 41,0 & 100,0 \\
\hline \multirow{4}{*}{$1-3$} & Count & 26 & 3 & 0 & 160 & 189 \\
\cline { 2 - 7 } & Expect. C. & 38,2 & 39,6 & 19,1 & 92,1 & 189,0 \\
\cline { 2 - 7 } & $\%$ & 13,8 & 1,6 & 0,0 & 84,7 & 100,0 \\
\hline \multirow{4}{*}{$4-6$} & Count & 74 & 109 & 9 & 211 & 403 \\
\cline { 2 - 7 } & Expect. C. & 81,4 & 84,5 & 40,7 & 196,4 & 403,0 \\
\cline { 2 - 7 } & $\%$ & 18,4 & 27,0 & 2,2 & 52,4 & 100,0 \\
\hline $7-9$ & Count & 38 & 38 & 4 & 75 & 155 \\
\cline { 2 - 7 } & Expect. C. & 31,3 & 32,5 & 15,7 & 75,5 & 155,0 \\
\cline { 2 - 7 } & $\%$ & 24,5 & 24,5 & 2,6 & 48,4 & 100,0 \\
\hline
\end{tabular}


Table 18. Crosstabulation for Number of Pirates Who Attacked and Type of Attacks (2009 - 2013) (Continued)

\begin{tabular}{|c|c|c|c|c|c|c|}
\hline & & & ype of & acks & & \\
\hline $\begin{array}{l}\text { Number of } \\
\text { pirates } \\
\text { who } \\
\text { attacked }\end{array}$ & $\begin{array}{l}\text { Count } \\
\% \text { within } \\
\text { hours of } \\
\text { attacks }\end{array}$ & Attempted & $\begin{array}{l}\text { Fired } \\
\text { upon }\end{array}$ & Hijack & Boarded & Total \\
\hline $10-12$ & Count & 25 & 19 & 16 & 44 & 104 \\
\hline & $\begin{array}{c}\text { Expect. } \\
\text { C. }\end{array}$ & 21,0 & 21,8 & 10,5 & 50,7 & 104,0 \\
\hline & $\%$ & 24,0 & 18,3 & 15,4 & 42,3 & 100,0 \\
\hline $13-19$ & Count & 8 & 0 & 4 & 13 & 25 \\
\hline & $\begin{array}{c}\text { Expect. } \\
\text { C. }\end{array}$ & 5,1 & 5,2 & 2,5 & 12,2 & 25,0 \\
\hline & $\%$ & 32,0 & 0,0 & 16,0 & 52,0 & 100,0 \\
\hline $20-$ & Count & 11 & 3 & 1 & 9 & 24 \\
\hline & $\begin{array}{l}\text { Expect. } \\
\text { C. }\end{array}$ & 4,8 & 5,0 & 2,4 & 11,7 & 24,0 \\
\hline & $\%$ & 45,8 & 12,5 & 4,2 & 37,5 & 100,0 \\
\hline Total & Count & 374 & 388 & 187 & 902 & 1851 \\
\hline & $\begin{array}{c}\text { Expect. } \\
\text { C. }\end{array}$ & 374,0 & 388,0 & 187,0 & 902,0 & 1851,0 \\
\hline & $\%$ & 20,2 & 21,0 & 10,1 & 48,7 & 100,0 \\
\hline
\end{tabular}

Source: ICC, IMB Piracy and Armed Robbery Against Ships Annual Reports 2009-2013.

The Pearson Chi Square value is 221,096 as shown in Table 19. The samples are simple random samples; all individual expected counts are more than 1 and $10,7 \%$ of expected counts are less than 5 . The minimum expected count is more than $1(2,42)$. The sample size requirement for the chi-square test of independence is satisfied. The Chi Square is used.

Hypothesis;

$\mathrm{H}_{0}$ : The number of pirates who attacked and type of attacks are independent.

$\mathrm{H}_{1}$ : The number of pirates who attacked and type of attacks are not independent. 
Table 19. The Chi-Square Test Between Number of Pirates Who Attacked and Type of Attacks (2009-2013)

\begin{tabular}{lccc}
\hline & Value & df & $\begin{array}{c}\text { Asymp.Sig. (2- } \\
\text { sided) }\end{array}$ \\
\hline Pearson Chi-Square & $221,096^{\mathrm{a}}$ & 18 & 0,000 \\
Likelihood Ratio & 268,246 & 18 & 0,000 \\
N of Valid Cases & 1851 & & \\
\hline
\end{tabular}

a. 3 cells $(10,7 \%)$ have expected count less than 5 . The minimum expected count is 2,42 .

$\mathrm{H}_{0}$ is rejected, $\mathrm{H}_{1}$ is accepted $(\mathrm{P}=0.00<\alpha=0.05)$. The number of pirates who attacked and type of attacks are not independent. Therefore, there is a statistical relationship exists between the two variables.

\section{CONCLUSION}

Piracy is an international crime that is subject to universal jurisdiction, which gives every state the right to prosecute and punish pirates. Piracy is on the rise, especially in Southeast Asia, and is becoming increasingly complex, better organized, and more violent. Especially economically hard hit by piracy are ship owners, exporters of shipped cargo, carriers and insurance firms. In addition to the grim economic forecasts, piracy is also the risk of a major environmental disaster. Attacks on oil tankers and other vessels carrying hazardous materials will not only disrupt world trade and cause a rise in insurance premiums, but would also severely endanger marine life.

This study will shed light on the studies concerning the maritime piracy attacks over all the world. The results and findings of the paper can be summarized as follows:

First, maritime piracy has reached its highest level with 445 attacks in 2010 and its lowest level with 264 attacks in 2013 recorded worldwide in the period of $2009-2013$.

Second, most of the attacks occurred between March and May and respectively between December and February, September and November and June and August in the period of $2009-2013$.

Third, most of these attacks occurred the hours between 24:01 04:00 (581 attacks) and respectively between 04:01 - 08:00 (376), 
20:00 - 24:00 (280), 12:00 - 16:00 (233), 08:01 - 12:00 (192) and 16:01 - 20:00 (135) in $2009-2013$.

Fourth, worldwide 902 vessels were boarded, 187 vessels hijacked, 374 vessels attempted and 388 vessels fired upon in 2009 2013. The most attack was boarded and increased to 202 in 2013 from 174 in 2012. The hijack is fell to 12 in 2013 from 28 in the previous year.

Fifth, most of these attacks occurred in Africa with the frequency 1044 attacks and respectively South East Asia with 428 attacks, America with 137 attacks, Indian Sub-Continent with 118 attacks and Far East with 110 attacks recorded in the period of $2009-2013$. The attacks in Africa have dropped significantly in 2009 - 2013, the attacks in South East Asia have increased from 105 in 2012 to 128 in 2013. The attacks in Indian Subcontinent Asia have increased to 26 in 2013 from 19 in 2012. The attacks in America have 1,1\% increased in 2013 according to previous year. The attacks in Far East have increased to 13 in 2013 from 7 in the previous year.

Sixth, most of these attacks occurred off the coast of Somalia with the frequency 435 and respectively Indonesia with 306, Gulf of Aden with 225, Nigeria with 112, Red Sea with 93, Bangladesh with 72 and Malaysia with 71, Malacca and Singapure Sraits with 46 in the period 2009 - 2013.

Attacks in Gulf of Aden recorded 6 attacks in 2013, down from 12 in 2012. The attacks in Gulf of Aden have dropped significantly in 2009 - 2013, the attacks in Somalia have dropped significantly to 7 in 2013 from 161 in 2011. The attacks in Indonesia have increased dramatically 105 in 2013 from 47 in 2011. The attacks in Nigeria have increased 30 in 2013 from 10 in 2011. Pirates / robbers are often well armed, violent and have attacked, hijacked and robbed vessels/kidnappedcrews along the coast, rivers, anchorages, ports and surrounding waters in Nigeria (Lagos) ((icc-ccs.org, 2015: 1). The attacks in India have increased significantly to 14 in 2013 from 5 in 2010.

Sixth, the ships most commonly attacked are bulk carriers (407) and respectively chemical tanker (288), container (266), tanker (230), general cargo (184) and product tanker (134). Attempted, boarded and fired upon attacks mostly occurred against to bulk carriers. Most were chemical tankers and fishing vessels, hijacked to steal and tranship their 
cargo into smaller tankers. Most were attempted attacks, fired upon and boarded against to bulk carriers.

Seventh, the ships most commonly were attacked in NE (01 49:00 - 59 N / 02 - 120:00 - 58 E) and respectively SE (00 - 27:00 - 59 S / 11 - 117:01 - 117), NW ( $02-18: 14-58 \mathrm{~N} / 00-83: 01-59 \mathrm{~W})$ and SW (01-21:00 - 46 S /08 - 81:09 - 59 W).

Eighth, attempted, fired upon and boarded incidents mostly occurred by $4-6$ pirates and hijack mostly occurred by $10-12$ pirates in the period of $2009-2013$.

Finally, The Chi Square $\left(\chi^{2}\right)$ Test was used to interpret the relationships between non-parametric variables for the years 2009 -2013. According to the results of Chi Square analysis; there is a statistical relationship exist between the non parametric variables as follows:

- Attacks by years and attacks by regions,

- Attacks by months and attacks by regions.

- Attacks by locations and years of attacks,

- Hours of attacks and type of attacks

- Attacks by years and type of attacks,

- Type of attacks and attacks by regions,

- Type of ships attacked and type of attacks,

- Type of attacks and latitude and longitude of attacks,

- Number of pirates who attacked against ships and type of attacks

In addition to internationally recognized security measures to combat maritime piracy, numerous anti-piracy measures are recommended such as; competency in crisis management; effective port and coast surveillance and control mechanisms; security plans for ships, port facilities, coasts and anchorages, to develop action plans for the attacks: technical collaboration for the full implementation of IMO standards and conventions; training of coastline personnel and crews, joint surveillance and patrol between states, effective information gathering and sharing; measures taken aboard the vessel to enhance selfdefense capability; tracking of financial flows and distrupting money flows concerning pirates; support international counter piracy efforts; strengthen national law, adoption of legislation and legal instruments to govern jurisdiction for instituting legal proceedings against pirates should be adopted. The legislation must be amended to create a legal framework for prosecuting pirates. Ships and boats should be advised to travel in 
convoys in International Recommended Transit Corridor (IRTC). All attacks or threats of attacks should be reported immediately to the nearest Rescue Co-ordination Centre (RCC) or coast radio station. Privately contracted armed security personnel on board commercial vessels are used. It was estimated that around $30 \%$ of ships employed private armed security in 2012. Moreover, the armed security personnel may lead to an escalation of violence. For legal and safety reasons, Flag States should strongly discourage the carrying and use of firearms by seafarers for personal protection or for the protection of a ship.

The piracy attacks have dropped significantly due to the efforts of increased/active military action anti-piracy operations, BMP recommendations, implementation of IRTC and deployment of privately contracted armed guards on board ships.

International community needs new strategies and a multidimensional approach is required to combat maritime piracy and armed robbery. International community should provide financial and social support to these countries to ensure maritime security and freedom of navigation on the high seas and strategic waters as a permanent solution.

\section{REFERENCES}

ALESSI, C. and HANSON, S. (2010) Combating Maritime Piracy, http:// www.cfr.org/publication/18376/combating_maritime_piracy.html.

Accessed: 12.05.2012.

BANIELA, S.I. (2010) Piracy at Sea: Somalia and Area of Great Concern, Journal of Navigation, Vol.63, No. 2, pp. 191-206.

BANIELA, S.I. and RIOS, J.V. (2012) Piracy in Somalia: A Challenge to The International Community, The Journal of Navigation, Vol. 65, No.4, pp. 693-702.

CHALK, P. (2008) The Maritime Dimension of International Security, pp.10. http://www.rand.org/pubs/monographs/2008/RAND_MG697.pdf. Accessed: 17.05.2012.

CHALK, P. (2009) Maritime Piracy Reasons, Dangers and Solutions. RAND Corporation, pp.2.

http://www.rand.org/content/dam/rand/pubs/testimonies/2009/RAND_CT 317.pdf. Accessed: 25.01.2015. 
CHANG, D. (2010) Piracy Laws and the Effective Prosecution of Pirates, Boston Collage International and Comparative Law Review, Vol.33, No. 2, pp. 275-277.

CHARlEBOIS, J. (2012) Pirate Economics: The Economic Causes and Consequences of Contemporary Maritime Piracy in Sub-Saharan Africa, Thesis for the degree of Master of Development Economics, Dalhousie University, Halifax, pp.12-13.

CHEW, F. (2005) Piracy, Maritime Terrorism and Regional Interests. http://www.defence.gov.au/ADC/Publications/Geddes/2005/PublcnsGedd es2005_310310_PiracyMaritime.pdf. Accessed: 27.01.2015.

CLASSNK (2015) IMO Resolutions \& Circulars.

http://www.classnk.com/hp/de/activities/statutory/ism/imo/index.html. Accessed: 23.01.2015.

COCHRAN, W. G. (1954) Some Methods for Strengthening the Common $\chi 2$ Tests, Biometrics, pp. 417-451.

ÇAYCI, S. (2009) The Struggle Against Piracy: The Somalia Case and Turkey's Position, Center For Middle Eastern Strategic Studies the Public Research Foundation, No: 1, pp. 9-12.

ECE, N.J. (2013) A Threat to Maritime Security: Piracy Attacks, SeaNews, No:4, pp. 30-32.

ECE, N.J. (2012) The Maritime Dimension of International Security: Piracy Attacks, NATO Science for Peace and Security Series - E: Human and Societal Dynamics, Maritime Security and Defence Against Terrorism, IOS Press, pp. 33-49.

ECE, N.J. (2010) Deniz Haydutluğu Saldırıları ve Analizi (Analysis of Piracy Attacks), Dokuz Eylül Universitesi Denizcilik Fakültesi Dergisi, Vol. No.2, pp. 1-22.

EU (European Union) (2015) EU legislation on Maritime Security, pp.1,2.http://ec.europa.eu/transport/modes/maritime/security/doc/legislati on_maritime_security.pdf. Accessed 20.01.2015. 
ICC INTERNATIONAL MARITIME BUREAU (2009) Piracy and Armed Robbery Against Ships Annual Report for the Period 1 January-31 December 2009, pp.1-103.

ICC INTERNATIONAL MARITIME BUREAU (2010) Piracy and Armed Robbery Against Ships Annual Report for the Period 1 January-31 December 2010, pp.1-99.

ICC INTERNATIONAL MARITIME BUREAU (2011) Piracy and Armed Robbery Against Ships Annual Report for the Period 1 January-31 December 2011, pp.1-109

ICC INTERNATIONAL MARITIME BUREAU (2012) Piracy and Armed Robbery Against Ships Annual Report for the Period 1 January-31 December 2012, pp. 1-83.

ICC INTERNATIONAL MARITIME BUREAU (2013) Piracy and Armed Robbery Against Ships Annual Report for the Period 1 January-31 December 2013, pp. 1-71.

ICC COMMERCIAL CRIME SERVICES (2015) Piracy \& Armed Robbery Prone Areas and Warnings, pp.1. https://www.iccccs.org/piracy-reporting-centre/prone-areas-and-warnings. Accessed: 26.01.2015).

IMO (2013a) The Djibouti Code of Conduct Resolution, pp.1.

http://www.imo.org/OurWork/Security/PIU/Pages/DCoC.aspx. Accessed: 28.09.2013.

IMO (2013b), AIS Transponders

http://www.imo.org/OurWork/Safety/Navigation/Pages/AIS.aspx.

Accessed: 26.01.2015.

IMO (2013c) Long-range Identification and Tracking (LRIT). http://www.imo.org/OurWork/Safety/Navigation/ Pages/LRIT.aspx. Accessed: 18.06.2013.

IMO (2009) Advice From IMO: Circulars on Somalia Piracy. http://www.imo.org/blast/mainframe.asp?topic_id=1613. Accessed: 23.01.2015. 
IMO (2015a) Piracy Guidance. pp.1,2.

http://www.imo.org/Documents/IMO_Piracy_Guidance.pdf. Accessed: 26.01.2015.

IMO (2015b) ISPS Code. pp.1.

http://www.imo.org/ourwork/security/instruments/pages/ispscode.aspx.

Accessed: 20.01.2015.

JOANA AMA OSEI-TUTU RESEARCH ASSOCIATE KOFI ANNAN INTERNATIONAL PEACEKEEPING TRAINING CENTER (KAIPTC) (2011) The Root Causes Of The Somali Piracy, pp.11.

http:/www.kaiptc.org/Publications/Occasional-Papers/Documents/

Occasional-Paper-31-Joana.aspx_.Accessed: 22.01.2015.

MENEFEE, S.P. (1998) Maritime Terror in Europe and the Mediterranean, Marine Policy, Vol 12, No.2, pp.143.

OILPRICE (2010) Piracy In The Puntland Region of Somalia.

http://oilprice.com/Geopolitics/Africa/Piracy-In-The-Puntland-Region-

Of-Somalia.html. Accessed: 22.01.2015.

ONE EARTH FUTURE FOUNDATION WORKING PAPERS (2012)

The Economic Cost of Somali Piracy, BIMCO, http://oceansbeyondpiracy.org/sites/ default/files/ecop2012final_2.pdf. Accessed: 06.06.2014.

REINHARDT, C.J. (2012) Maritime Piracy: Sign of a Security Threat?, Mercer on Transport \& Logistics. http://www.oliverwyman.com/pdf files/MOTL-MaritimePiracy.pdf. Accessed: 17.05.2012.

SHESKIN, D. J. (2004) Handbook of Parametric and Nonparametric Statistical Procedures, Boca Raton: Chapman \& Hall/CRC, New York, pp. 494-495.

UNEP (United Nations Environment Programme) (2005) National Rapid Environmental Desk Assessment - Somalia, pp. 133-134, http://www.unep.org/tsunami/reports/TSUNAMI_SOMALIA_LAYOUT. pdf, Accessed: 08.01.2015. 
UNITED NATIONS WORLD FOOD PROGRAME (2009) Somali Pirates Hijack 2 Tankers in 24 Hours, http://www.wfp.org/countries/somalia/news/hunger-in-thenews?page=53, Accessed: 20.01.2015.

US ENERGY INFORMATION ADMINISTRATION (EIA) World Oil Transit Chokepoints, pp.1. http://www.eia.gov/countries/regionstopics.cfm?fips=wotc\&trk=p3, Accessed: 24.01.2015. 